\title{
Perilaku Masyarakat dalam Pelestarian Hutan Mangrove di Kabupaten Pangkep Provinsi Sulawesi Selatan
}

\section{Coastal Communities Behaviour in Managing and Conserving The Mangrove Forest in Pangkep District of South Sulawesi Province}

\author{
Zainudin $^{1}$, Sumardjo ${ }^{2}$ dan Djoko Susanto ${ }^{3}$ \\ ${ }^{1}$ Balai Pelatihan Kehutanan, Maros, Sulawesi Selatan \\ ${ }^{2}$ Departemen Sains Komunikasi dan Pengembangan Masyarakat, \\ Fakultas Ekologi Manusia, Institut Pertanian Bogor, Bogor \\ ${ }^{3}$ Pusat Penelitian dan Pengembangan Kesehatan, Jakarta
}

\begin{abstract}
Mangrove forest is one natural resource which essential for the life of living creatures that lives on its surrounding. The existence of mangrove forests has become an integral part of the lives of coastal communities; hence the existence of mangrove forests should be maintained and preserved. Mangrove forest sustainability cannot be separated from the behavior of the people who live around that forest. The objective of this research was (1) to examine the behavior of the coastal communities conserving mangrove forests, (2) to examine the factors related to coastal communities' behavior in managing and conserving mangrove forest. The populations were the 100 heads of fisherman households taken from Tekolabbua and Pundata Baji Village of Pangkep District. This research was correlational research. This data was analyzed using Spearman Rank correlation by using SPSS programming. The result shows that the behavior of coastal communities in the preservation Pangkep mangrove forests is in the middle level. Factors related to this are behavior is the intensity of extension activities and environmental support.
\end{abstract}

Keywords: coastal community behavior, managing and conserving mangrove forests

\begin{abstract}
Abstrak
Hutan Mangrove merupakan salah satu sumberdaya alam yang sangat penting bagi kehidupan makhluk hidup yang berada di dalamnya atau di sekitarnya. Keberadaan hutan mangrove sudah menjadi bagian yang tidak terpisahkan dari kehidupan masyarakat pesisir, oleh karenanya keberadaan hutan mangrove perlu dijaga dan dilestarikan. Kelestarian hutan mangrove tidak terlepas dari perilaku masyarakat yang berada di sekitarnya. Penelitian ini bertujuan untuk mengkaji perilaku masyarakat dalam pelestarian hutan mangrove dan mengkaji faktor-faktor yang berhubungan dengan perilaku masyarakat dalam pelestarian hutan mangrove. Populasi penelitian adalah kepala keluarga masyarakat di Kelurahan Tekolabbua Kecamatan Pangkajene dan Kelurahan Pundata Baji Kecamatan Labakkang Kabupaten Pangkep Provinsi Sulawesi Selatan. Jumlah sampel dalam penelitian ini sebanyak 100 sampel. Penarikan sampel dilakukan secara acak klaster (Cluster random sampling). Penelitian ini merupakan penelitian deskriptif korelasional. Data yang diperoleh dianalisis dengan menggunakan korelasi Rank Spearman SPSS 20. Hasil penelitian menunjukkan bahwa perilaku masyarakat pesisir Kabupaten Pangkep dalam pelestarian hutan mangrove tergolong dalam kategori sedang. Faktor-faktor yang berhubungan dengan perilaku masyarakat dalam pengelolaan hutan magrove secara lestari adalah intensitas penyuluhan dan dukungan lingkungan.
\end{abstract}

Kata kunci: perilaku masyarakat, pelestarian hutan mangrove

\section{Pendahuluan}

Hutan mangrove merupakan salah satu ekosistem wilayah pesisir dan lautan yang sangat penting bagi kehidupan manusia dan keberlangsungan makhluk hidup yang tinggal di dalamnya atau di sekitarnya, namun keberadaannya sudah semakin kritis. Luas areal hutan mangrove di Provinsi Sulawesi Selatan sekitar 112.577 hektar pada tahun 80-an, saat ini tinggal seluas 22.353 hektar (Konsorsium Mitra Bahari Sulawesi Selatan 2010).
Kerusakan terjadi hampir di seluruh kawasan pesisir pantai Provinsi Sulawesi Selatan. Perwakilan dari Mangrove Action Project-Internationa/Robin Lewis III mengatakan bahwa kerusakan hutan mangrove di Provinsi Sulawesi Selatan memanjang dari wilayah pesisir pantai barat yang mencakup Kabupaten Pangkep, Maros, Takalar, hingga ke wilayah pantai timur, mulai dari Kabupaten Sinjai hingga daerah Luwu Raya (Tribun Timur, 2011). Hutan mangrove adalah salah satu ekosistem pesisir yang mengalami tingkat degradasi yang cukup tinggi akibat pola

\footnotetext{
${ }^{1}$ Korespondensi penulis

E-mail: zai_walla@yahoo.com
} 
pemanfaatan lingkungan yang cenderung tidak memperhatikan aspek kelestariannya (Raymond et al., 2010).

Kabupaten Pangkep adalah salah satu wilayah di Provinsi Sulawesi Selatan yang memiliki luas kawasan pesisir sebesar 781,13 kilometer persegi atau $70 \%$ dari luas daratan, dengan panjang garis pesisir sepanjang 95 kilometer. Pada rentang waktu 2003 sampai dengan 2007, kawasan hutan mangrove di sepanjang kawasan pesisir di Kabupaten Pangkep banyak mengalami konversi atau alih fungsi menjadi tambak. Selama rentang waktu itu, luas tambak yang telah dikembangkan seluas 3.311,32 hektar tambak dengan komoditas utama yaitu udang dan bandeng (Mayudin, 2012). Hal ini mengakibatkan luasan hutan mangrove semakin terdegradasi.

Konversi hutan mangrove untuk pengembangan kegiatan perikanan tambak akan berdampak pada kondisi ekonomi masyarakat di sekitarnya seperti penyerapan tenaga kerja lokal dan peningkatan tingkat kesejahteraan masyarakat (Nurfiarini, 2003). Hasil penelitian Tantu (2012) di Kecamatan Labakkang Kabupaten Pangkep menemukan perubahan bentang lahan dari tahun 1980 sampai tahun 2010 sebagai akibat alih fungsi dari hutan mangrove menjadi lahan tambak. Selanjutnya dinyatakan Tantu bahwa vegetasi mangrove berkurang dari 248,4 hektar menjadi 49,0 hektar, sementara luas tambak meningkat dari 2.251,4 hektar menjadi 5.029,3 hektar. Apabila fenomena kerusakan kawasan hutan mangrove di Kabupaten Pangkep terus berlanjut dan tidak segera ditangani maka akan berakibat sangat buruk bagi ekologi hutan mangrove tersebut dan berdampak pada terjadinya abrasi pantai yang semakin kritis, intrusi air laut lebih jauh ke daratan, potensi perikanan menurun, kehidupan satwa liar dan berbagai jenis habitat lainnya terganggu serta sumber pendapatan masyarakat sekitar berkurang. Oleh karena itu, ekosistem mangrove perlu dilestarikan agar dapat memperoleh manfaat yang sebesar-besarnya pada masa sekarang dan masa yang akan datang.

Upaya mewujudkan pelestarian hutan, termasuk hutan mangrove, dilakukan oleh pemerintah dengan mengeluarkan kebijakan, yakni Undang-Undang Nomor 41 Tahun 1999 tentang Kehutanan dimana pada pasal 2 dinyatakan bahwa mangrove merupakan ekosistem hutan, dan oleh karena itu, pemerintah bertanggungjawab dalam pengelolaan yang berasaskan manfaat dan lestari, kerakyatan, keadilan, kebersamaan, keterbukaan dan keterpaduan. Selanjutnya dipertegas dalam pasal 43 bahwa dalam kaitan kondisi mangrove yang rusak, kepada setiap orang yang memiliki, pengelola dan atau memanfaatkan hutan kritis atau produksi, wajib melaksanakan rehabilitasi hutan untuk tujuan perlindungan konservasi. Dengan demikian, kelestarian hutan mangrove tidak terlepas dari kesadaran dan perilaku masyarakat dalam mengelola dan juga memanfaatkan hutan mangrove untuk mempertahankan kelestarian sekaligus meningkatkan sumber pendapatan masyarakat nelayan dan petani tepian pantai yang kehidupannya sangat tergantung kepada sumberdaya alam hutan mangrove.

Kerusakan hutan mangrove di Kabupaten Pangkep masih berlangsung sampai dengan saat ini, sebagai akibat terjadinya alih fungsi hutan dan juga karena kondisi hutan yang rusak disebabkan kurangnya kepedulian berbagai pihak atas kelestarian hutan tersebut. Salah satu pihak yang dapat menjadi pilar penting bagi terpeliharanya hutan mangrove adalah masyarakat yang tinggal di sekitar hutan tersebut. Perilaku masyarakat sekitar hutan mangrove Kabupaten Pangkep dapat menjadi dukungan yang sangat berarti bagi kelestarian hutan mangrove. Hutan mangrove akan terjaga apabila masyarakat yang tinggal di sekitarnya memiliki perilaku yang positif terhadap hutan tersebut.

Berdasarkan argumen di atas, maka masalah penelitian dapat dirumuskan sebagai berikut: 1) Bagaimana perilaku masyarakat dalam pelestarian hutan mangrove di Kabupaten Pangkep? 2) Faktorfaktor apa yang berhubungan dengan perilaku masyarakat dalam pelestarian hutan mangrove di Kabupaten Pangkep? Penelitian ini bertujuan untuk mendeskripsikan perilaku masyarakat dalam melestarikan hutan mangrove di Kabupaten Pangkep dan menganalisis faktor-faktor yang berhubungan dengan perilaku masyarakat dalam pelestarian hutan mangrove di Kabupaten Pangkep.

\section{Metode Penelitian}

Lokasi penelitian ditentukan secara sengaja yaitu di wilayah dimana masih terdapat hutan mangrove. Dua lokasi dipilih yaitu Kelurahan Tekolabbua Kecamatan Pangkajene Kabupaten Pangkep dimana terdapat kegiatan masyarakat 
dalam pelestarian hutan mangrove, dan Kelurahan Pundata Baji Kecamatan Labakkang Kabupaten Pangkep dimana terdapat kerusakan hutan mangrove karena tidak dikelola dengan baik. Penelitian dilaksanakan pada bulan Juli sampai dengan bulan September 2013. Populasi penelitian adalah 701 Kepala Keluarga masyarakat pesisir. Jumlah sampel penelitian ini sebanyak $100 \mathrm{KK}$ dengan rincian 60 KK dari Kelurahan Tekollabua dan 40 KK dari Kelurahan Pundata Baji. Jumlah ini sesuai dengan pendapat Gay yang dikutip Sevilla et al. (1993) bahwa untuk penelitian korelasional diperlukan minimal 30 subyek, dan menurut Bailey (Chadwick et al. 1991), bahwa jumlah sampel minimal adalah 30 sampai 100 satuan. Penarikan sampel dilakukan secara acak kelompok (cluster random sampling), dimana mula-mula diambil dua kelompok Kelurahan yaitu Tekkolabua dan Pundata Baji, kemudian dari setiap kelompok diambil responden yang dilakukan secara acak. Pengumpulan data primer dilakukan dengan cara pengisisan kuesioner, wawancara dan pengamatan langsung. Data sekunder diperoleh dari kantor Desa/ Kelurahan, kantor Kecamatan, Dinas Kehutanan Kabupaten setempat dan instansi terkait lainnya. Pengolahan dan analisa data, untuk mengetahui hubungan peubah $\mathrm{X}$ dengan peubah $\mathrm{Y}$, menggunakan analisa korelasional rank Spearman dengan bantuan program SPSS 20 for windows. Untuk analisis deskripsi data ditransformasi sehingga memiliki kisaran yang sama yaitu $0-100$.

\section{Hasil dan Pembahasan}

\section{Karakteristik Individu Masyarakat}

Karakteristik individu masyarakat pengelola hutan mangrove pada umumnya berada pada usia produktif $(75 \%)$ dengan kategori umur 15 49 tahun dengan rataan umur 38,7 tahun. Hal ini menunjukkan potensi tersedianya tenaga kerja pedesaan bagi upaya pengelolaan hutan mangrove. Ditinjau dari faktor usia, masyarakat di sekitar hutan mangrove merupakan sumberdaya manusia yang potensial untuk dikembangkan dan ditingkatkan kemampuannya dalam upaya pelestarian hutan mangrove.

Secara umum sebagian besar (83\%) dari masyarakat memiliki tingkat pendidikan yang rendah. Rendahnya tingkat pendidikan responden disebabkan oleh faktor ekonomi dan rendahnya kesadaran orang tua untuk menyekolahkan anaknya. Orang tua beranggapan bahwa tanpa sekolah yang tinggi, asalkan anak dapat bekerja dengan tekun dan giat, maka secara langsung dapat meningkatkan taraf hidupnya kelak. Rendahnya tingkat pendidikan masyarakat bukan berarti mereka tidak mampu mengelola hutan mangrove dengan baik tetapi masyarakat telah mendapatkan bekal atau ilmu tentang cara mengelola hutan mangrove secara turun temurun.

Pendapatanresponden secara umum termasuk dalam kategori sedang dengan rata-rata pendapatan $\mathrm{Rp} 1.650 .500$ per bulan. Sumber pendapatan berasal dari usaha memanfaatkan kawasan hutan mangrove seperti budidaya tambak ikan, udang dan usaha-usaha lainnya di luar pengelolaan mangrove. Masyarakat belum memanfaatkan keberadaan hutan mangrove secara optimal, hal ini terjadi karena berdasarkan wawancara bahwa masyarakat belum mengetahui cara mengelola hasil mangrove menjadi produk olahan yang memiliki nilai jual yang layak.

Tingkat pengalaman responden dalam pengelolaan hutan mangrove pada umumnya termasuk dalam kategori sedang dengan rataan pengalaman mengelola hutan yaitu 17,4 tahun. Responden menyatakan bahwa sejak kecil mereka telah mengelola hutan mangrove untuk memenuhi kebutuhan hidup sehari-hari. Namun, pengelolaan ini masih sebatas memanfaatkan kawasan dan kayu mangrove. Upaya untuk menjaga, melindungi dan melestarikan masih belum dilakukan secara optimal. Masyarakat mengelola hutan mangrove sesuai dengan kemampuannya dan pengetahuan yang mereka miliki. Seiring berjalannya waktu, sedikit demi sedikit pengetahuan dan kesadaran masyarakat untuk melestarikan sumberdaya alam dan lingkungan di sekitarnya bertambah. Kesadaran tersebut termanifestasi dalam bentuk perilaku. Masyarakat telah melibatkan diri dalam pelaksanaan kegiatan pengembangan dan pengelolaan hutan mangrove secara bijaksana, proporsional dan berkelanjutan yang berdampak pada peningkatan kesejahteraan masyarakat dan kelestarian hutan mangrove.

\section{Intensitas Penyuluhan}

Intensitas penyuluhan dalam suatu program kegiatan sangat bergantung pada interaksi yang 
Tabel 1 Karakteristik individu masyarakat dalam pelestarian hutan mangrove di Kabupaten Pangkep

\begin{tabular}{|c|c|c|c|c|c|c|c|}
\hline \multirow{2}{*}{ Peubah } & \multirow{2}{*}{ Kategori } & \multicolumn{2}{|c|}{$\begin{array}{c}\text { Tekolabbua } \\
\text { (60) }\end{array}$} & \multicolumn{2}{|c|}{$\begin{array}{c}\text { Pundata Baji } \\
\text { (40) }\end{array}$} & \multicolumn{2}{|c|}{$\begin{array}{l}\text { Total } \\
\text { (100) }\end{array}$} \\
\hline & & $\begin{array}{c}\text { Jml. } \\
\text { (orang) }\end{array}$ & $\%$ & $\begin{array}{c}\text { Jml. } \\
\text { (orang) }\end{array}$ & $\%$ & $\begin{array}{c}\text { Jml. } \\
\text { (orang) }\end{array}$ & $\%$ \\
\hline \multirow[t]{4}{*}{ Umur } & Tidak produktif (65 tahun ke atas) & 1 & 1,7 & 0 & 0,0 & 1 & 1,0 \\
\hline & Kurang profuktif (50-64 tahun) & 14 & 23,3 & 10 & 25,0 & 24 & 24,0 \\
\hline & Produktif (15-49 tahun) & 45 & 75,0 & 30 & 75,0 & 75 & 75,0 \\
\hline & Rataan Umur & & 39,6 & & 37,5 & & 38,7 \\
\hline \multirow{3}{*}{$\begin{array}{l}\text { Tingkat } \\
\text { Pendidikan }\end{array}$} & Rendah (SD) & 53 & 88,3 & 30 & 75,0 & 83 & 83,0 \\
\hline & Sedang (SMP) & 3 & 5,0 & 7 & 17,5 & 10 & 10,0 \\
\hline & Tinggi (SMA/Sarjana) & 4 & 6,7 & 3 & 7,5 & 7 & 7,0 \\
\hline \multirow{4}{*}{$\begin{array}{c}\text { Jumlah } \\
\text { Pendapatan }\end{array}$} & Rendah $(<$ Rp.853.500) & 8 & 13,3 & 14 & 35,0 & 22 & 22,0 \\
\hline & Sedang (Rp 853.500-Rp 3.362.500) & 48 & 80,0 & 23 & 57,5 & 71 & 71,0 \\
\hline & Tinggi (>Rp 3.362.500) & 4 & 6,7 & 3 & 7,5 & 7 & 7,0 \\
\hline & Rataan pendapatan (Rp) & 1.836 & & 1.371. & & 1.650 .5 & \\
\hline \multirow{4}{*}{$\begin{array}{l}\text { Tingkat } \\
\text { Pengalaman }\end{array}$} & Rendah (1-10 tahun) & 18 & 30,0 & 24 & 60,0 & 42 & 42,0 \\
\hline & Sedang (11-30 tahun) & 20 & 33,3 & 13 & 32,5 & 33 & 33,0 \\
\hline & Tinggi (31 tahun ke atas) & 22 & 36,7 & 3 & 7,5 & 25 & 25,0 \\
\hline & Rataan Tahun & & 20,3 & & 12,3 & & 17,4 \\
\hline
\end{tabular}

terjadi antara penyuluh dengan lingkungan. Secara umum tingkat intensitas penyuluh berada dalam kategori sedang yang ditunjukan oleh rataan skor 38,5. Pada umumnya frekuensi kunjungan penyuluh masuk dalam kategori sedang, dengan rataan skor 33,8. Namun bila dilihat secara parsial frekuensi kunjungan penyuluh di Tekolabbua kategori sedang dengan skor rataan 42,8, sedangkan di Pundata Baji dalam kategori rendah dengan rataan skor 26,3. Kegiatan penyuluhan wilayah Kelurahan Tekolabbua dilaksanakan sebanyak dua kali sebulan, sedangkan di Kelurahan Pundata Baji kunjungan penyuluh tidak terjadwal.

Kesesuaian materi, secara umum berada dalam kategori sedang yang ditunjukkan oleh rataan skor 51,3. Kesesuaian materi menurut responden dari Kelurahan Tekolabbua masuk dalam kategori sedang dengan rataan skor 63,8, sedangkan di Kelurahan Pundata Baji dalam kategori rendah dengan rataan skor 32,7. Materi pembelajaran yang diberikan oleh para penyuluh, menurut masyarakat
Tekolabbua dirasakan telah cukup sesuai dan dapat menjawab permasalahan yang sedang dihadapi oleh responden. Namun berbeda di Kelurahan Pundata Baji, minat masyarakat untuk mengelola hutan mangrove sangat kurang walaupun mereka telah mempunyai pengalaman tentang pengelolaan kawasan hutan mangrove. Masyarakat di Pundata Baji merasakan bahwa mereka yang terlibat sebagian besar hanya pengurus kelompok tanpa melibatkan para anggotanya, sehingga kurang terjalin hubungan kerjasama yang baik antara pengurus kelompok dengan masyarakat. Rakhmat(2002) mengemukakan bahwa faktor situasional sangat besar pengaruhnya dalam menentukan perilaku manusia. Manusia akan memberikan reaksi yang berbeda-beda terhadap situasi yang dihadapi sesuai dengan karakteristik personal yang dimilikinya.

Ketepatan metode secara umum berada dalam kategori sedang dengan rataan skor 34,1. Di Tekolabbua dalam kategori sedang dengan rataan skor 44,2 dan di Pundata Baji kategori rendah dengan 
Tabel 2 Rataan skor peubah penelitian perilaku masyarakat dalam pelestarian hutan mangrove di Kabupaten Pangkep

\begin{tabular}{llccc}
\hline \multicolumn{1}{c}{ Peubah } & \multicolumn{1}{c}{ Indikator } & $\begin{array}{c}\text { Tekolabbua } \\
(\mathbf{6 0 )}\end{array}$ & $\begin{array}{c}\text { Pundata } \\
\text { Baji (40) }\end{array}$ & $\begin{array}{c}\text { Total } \\
(\mathbf{1 0 0})\end{array}$ \\
\hline 1. Intensitas & Frekuensi Kunjungan Penyuluh & 35,4 & 31,4 & 33,8 \\
Penyuluhan & Kesesuaian Materi & 63,8 & 32,7 & 51,3 \\
& Ketepatan Metode & 44,2 & 19,0 & 34,1 \\
& Ketersediaan Sarana & 42,8 & 26,7 & 36,3 \\
& Rataan skor & 46,7 & 26,3 & 38,5 \\
2. Dukungan & Dukungan Tokoh Masyarakat & 61,0 & 31,8 & 49,3 \\
Lingkungan & Dukungan Kelompok Tani & 57,9 & 30,0 & 46,7 \\
& Dukungan Pemerintah & 57,0 & 32,5 & 47,2 \\
& Rataan skor & 58,6 & 32,5 & 51,1 \\
3. Perilaku & Tingkat Pemanfaatan Kawasan Hutan & 71,9 & 25,6 & 53,3 \\
Masyarakat & Mangrove & & & \\
& Tingkat Pengelolaan Hutan Mangrove & 63,2 & 26,4 & 48,5 \\
& Kreativitas Membangun Kemitraan & 63,7 & 31,0 & 50,6 \\
& Rataan skor & 65,2 & 27,9 & 50,3 \\
\hline
\end{tabular}

Keterangan: Kategori rendah $(0-<33,3)$,

Kategori sedang $(33,3-<66,7)$,

Kategori tinggi $(66,7-100)$.

rataan skor 19,0. Penilaian tersebut disebabkan belum banyaknya inovasi dan improvisasi yang ditunjukkan oleh penyuluh dalam meng-gunakan metode pembelajaran. Metode pembelajaran yang dilakukan lebih banyak tatap muka.

Ketersediaan sarana secara umum berada dalam kategori sedang yang ditunjukkan dengan rataan skor 36,3. Ketersediaan sarana di Tekolabbua dalam kategori sedang dengan rataan skor 44,8 dan di Pundata Baji kategori rendah dengan rataan skor 26,7. Sarana yang tersedia pada saat dilakukan kegiatan penyuluhan berupa papan tulis, meja dan lainnya, namun sarana ini banyak yang mengalami kerusakan. Media seperti majalah, koran, leaflet dan media lainnya tersedia dalam jumlah terbatas, padahal media merupakan sumber informasi yang sangat penting untuk mengetahui perkembangan dan peristiwa yang terjadi saat sekarang.

\section{Dukungan Lingkungan}

Dukungan lingkungan secara umum berada dalam kategori sedang dengan rataan skor 51,1. Dukungan tokoh masyarakat pada umumnya berada dalam kategori sedang dengan rataan skor 49,3. Terdapat perbedaan di antara dua Kelurahan, di
Tekolabbua dukungan tokoh masyarakat dalam kategori sedang dengan rataan skor 61,0 sedangkan di Kelurahan Pundata Baji dalam kategori rendah dengan rataan skor 31,8. Penilaian masyarakat di Kelurahan Tekolabbua mengenai dukungan tokoh masyarakat mengindikasikan bahwa tokoh masyarakat cukup mendukung kegiatankegiatan yang dilakukan masyarakat. Berbeda halnya di Kelurahan Pundata Baji dukungan tokoh masyarakat belum optimal, tokoh masyarakat kurang memperdulikan keberadaan hutan mangrove atau aktivitas masyarakat di sekitar kawasan hutan mangrove. Tokoh masyarakat akan terlihat perannya, jika ada kunjungan lapang dari instansi terkait mengenai hutan mangrove.

Dukungan kelompok tani secara umum berada dalam kategori sedang dengan rataan skor 46,7. Terdapat perbedaan nyata dukungan kelompok tani di dua Kelurahan tersebut, di Kelurahan Tekolabbua dukungan kelompok tani terkategori sedang dengan rataan skor 57,9, sedangkan pada Kelurahan Pundata Baji terkategori rendah dengan skor rataan 30,0. Kelompok tani di Kelurahan Tekolabbua terbentuk sejak tahun 1991 dengan nama Kelompok Tani Nelayan Sejahtera. Keberadaan kelompok tani di Kelurahan Tekolabbua sangat 
Tabel 3 Nilai koefisien korelasi karakteristik individu, intensitas penyuluhan dan dukungan lingkungan dengan perilaku masyarakat dalam pelestarian hutan mangrove di Kabupaten Pangkep

\begin{tabular}{|c|c|c|c|c|c|c|}
\hline \multirow[b]{2}{*}{ No } & \multirow[b]{2}{*}{ Peubah } & & \multirow[b]{2}{*}{ Indikator } & \multicolumn{3}{|c|}{ Perilaku Masyarakat } \\
\hline & & & & $\begin{array}{c}\text { Tingkat } \\
\text { Pemanfaatan } \\
\text { Hut.mangrove }\end{array}$ & $\begin{array}{c}\text { Tingkat } \\
\text { Pengelolaan } \\
\text { Hut.mangrove }\end{array}$ & $\begin{array}{c}\text { Kreativitas } \\
\text { Membangun } \\
\text { Kemitraan }\end{array}$ \\
\hline \multirow[t]{4}{*}{1} & $\begin{array}{l}\text { Karakteristik } \\
\text { Individu }\end{array}$ & - & Umur & 0,017 & $-0,048$ & -0.095 \\
\hline & & - & Tingkat Pendidikan & $-0,107$ & 0,240 & 0,163 \\
\hline & & - & Jumlah Pendapatan & $-0,123$ & 0,015 & $-0,092$ \\
\hline & & - & Tingkat Pengalaman & $-0,136$ & $-0,090$ & -0.176 \\
\hline \multirow[t]{4}{*}{2} & $\begin{array}{l}\text { In t e } \mathrm{n} \mathrm{s} \text { it a s } \\
\text { penyuluhan }\end{array}$ & - & Frekuensi kunjungan & $0,440 * *$ & $0,321^{*}$ & $0,285^{*}$ \\
\hline & & - & Kesesuaian Materi & $0,604 * *$ & $0,479 * *$ & $0,527^{* *}$ \\
\hline & & - & Katepatan metode & $0,637^{* *}$ & $0,633^{* *}$ & $0,701 * *$ \\
\hline & & - & Ketersediaan sarana & $0,668^{* *}$ & $0,668^{* *}$ & $0,667^{* *}$ \\
\hline \multirow[t]{3}{*}{3} & $\begin{array}{l}\text { D u k u n g a } \mathrm{n} \\
\text { Lingkungan }\end{array}$ & $\begin{array}{l}\text { - } \\
\text { yarakat }\end{array}$ & Dukungan tokoh mas- & $0,318^{*}$ & $0,682 * *$ & $0,503^{* *}$ \\
\hline & & 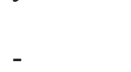 & Dukungan kelompok tani & $0,263^{*}$ & $0,540 * *$ & $0,428 * *$ \\
\hline & & - & Dukungan pemerintah & $0,559 * *$ & $0,755^{* *}$ & $0,711^{* *}$ \\
\hline$*$ & $\begin{array}{l}\text { Berhubungan } \\
\text { Berhubungan }\end{array}$ & sangat & $\begin{array}{l}\text { da } a 0,05 \\
\text { yata pada } a 0,01\end{array}$ & & & \\
\hline
\end{tabular}

membantu masyarakat dalam memecahkan suatu masalah. Kelompok tani telah menjadi wadah bagi masyarakat untuk saling bertukar pikiran dan informasi, mencari solusi terhadap masalah yang dihadapi. Sebaliknya kelompok tani yang ada di Kelurahan Pundata Baji merupakan kelompok tani dadakan, artinya kelompok tani terbentuk karena ada kegiatan saja. Tujuan terbentuknya kelompok tani hanya untuk mendukung kegiatan-kegiatan proyek dari instansi terkait termasuk perikanan dan kelautan maupun kehutanan.

Dukungan pemerintah secara umum dalam kategori sedang dengan rataan skor 47,2. Temuan penelitian menunjukkan bahwa pemerintah cukup memberikan dukungan bagi masyarakat di kelurahan Tekolabbua dalam mengelola dan melestarikan hutan mangrove dengan rataan skor 57,0. Artinya dukungan oleh pemerintah sebagai pihak pengambil keputusan dan pemberi kebijakan cukup sesuai dengan harapan masyarakat sekitar kawasan hutan mangrove. Berbeda dengan Kelurahan Tekolabbua, dukungan pemerintah di Kelurahan Pundata Baji terkategori rendah dengan rataan skor yakni 32,5.
Dukungan pemerintah hanya sebatas ketika ada kegiatan. Pemerintah hanya berkunjung ke lokasi pada saat kegiatan proyek akan diluncurkan. Pengawasan sebagai tindak lanjut dari kegiatan untuk memantau keberhasilan kegiatan/proyk dapat dikatakan hampir tidak ada.

\section{Perilaku Masyarakat dalam Pelestarian Hutan Mangrove}

Perilaku masyarakat dalam pelestarian hutan mangrove secara umum terkategori sedang, hal ini ditandai dengan rataan skor 50,3. Pada umumnya perilaku masyarakat dalam memanfaatkan kawasan hutan mangrove dalam kategori sedang ditandai dengan rataan skor 53,3, Terdapat perbedaan perilaku masyarakat di Kelurahan Tekolabbua dan Kelurahan Pundata Baji dalam memanfaatkan kawasan hutan mangrove. Pemanfaatan kawasan hutan mangrove di Kelurahan Tekolabua tergolong tinggi, dengan rataan skor 71,9 sebaliknya tingkat pemanfaatan hutan mangrove di Kelurahan Pundata Baji tergolong rendah, dengan rataan skor 25,6. Masyarakat di Kelurahan Tekolabbua telah menyadari bahwa 
banyaknya manfaat yang diperoleh dari keberadaan hutan mangrove. Keberadaan wilayah hutan mangrove dapat memberikan konstribusi yang cukup besar bagi kehidupan mahluk hidup yang juga berada di dalamnya. Tersedianya pakan dari serasah mangrove mengakibatkan jumlah populasi ikan bertambah, sehingga masyarakat dengan mudah menangkap ikan dan biota air lainnya di sekitar kawasan hutan mangrove seperti kepiting, kerang dan lainnya yang berada di bawah tegakan mangrove. Masyarakat di sekitar hutan mangrove dalam memanfaatkan dan mengelola wilayah hutan dengan tetap memperhatikan aspek kelestariannya.

Tingkat pengelolaan hutan mangrove berada dalam kategori sedang, dengan rataan skor 48,5. Tingkat pengelolaan hutan mangrove di Tekolabbua berada dalam kategori sedang dengan rataan skor 63,2, sementara di Kelurahan Pundata Baji terkategori rendah dengan rataan skor 26,4. Masyarakat Tekolabbua secara langsung aktif dalam kegiatan pengelolaan hutan mangrove. Masyarakat Tekolabbua telah memiliki kesadaran arti penting dari kelestarian hutan mangrove sehingga perlu dikelola dengan baik yang kemudian teraktualisasi dalam tindakan nyata melalui pengelolaan wilayah yang meliputi pembibitan, penanaman, pemeliharaan dan pengawasan. Sedangkan masyarakat di Kelurahan Pundata Baji sangat jarang mengelola hutan mangrove yang ada di sekitarnya, karena telah terjadi alihfungsi hutan mangrove menjadi usaha tambak. Alih fungsi lahan menjadi areal tambak membuat keberadaan dan luas hutan mangrove semakin berkurang.

Kreativitas masyarakat dalam membangun kemitraan berada dalam kategori sedang dengan rataan skor 50,6. Namun demikian bila dilihat secara parsial terdapat perbedaaan tingkat kreativitas antara responden di Tekolabbua dengan di Pundata Baji. Tingkat kreativitas membangun kemitraan di wilayah Tekolabbua tergolong sedang dengan rataan skor yakni 63,7, sedangkan di Pundata Baji terkategori rendah dengan rataan skor 31,0.

\section{Faktor-Faktor yang Berhubungan dengan Perilaku Masyarakat dalam Pelestarian Hutan Mangrove di Kabupaten Pangkep}

Hasil analisis hubungan karakteristik individu berkaitan dengan pengelolaan hutan mangrove menunjukkan bahwa tidak terdapat hubungan secara nyata antara umur, tingkat pendidikan, jumlah pendapatan dan tingkat pengalaman dengan perilaku masyarakat dalam pelestarian hutan mangrove. Ketiadaan hubungan ini, secara statistik, menunjukkan bahwa berapapun umur, jumlah pendapatan, dan apapun tingkat pendidikan serta tingkat pengalaman yang dimiliki oleh masyarakat maka perilaku masyarakat dalam pelestarian hutan mangrove pada umumnya relatif sama. Hal ini terjadi karena pada umumnya, masyarakat merasakan bahwa mereka mempunyai kebiasaan yang relatif sama dalam memanfaatkan dan mengelola hutan mangrove, yang kemudian teraktualisasi dalam perilaku melestarikan.

Terdapat hubungan positif sangat nyata antara indikator intensitas penyuluhan dengan indikator-indikator pada perilaku masyarakat (Tabel 3). Artinya semakin tinggi frekuensi kunjungan penyuluh kepada masyarakat sekitar kawasan hutan mangrove, maka semakin baik perilaku masyarakat terhadap pemanfaatan dan juga pengelolaan hutan mangrove. Temuan ini sejalan dengan temuan Sujarwo (2004) yaitu semakin tinggi tingkat penyuluhan yang dilakukan, maka semakin baik perilaku masyarakat sekitar hutan dalam pelestarian hutan. Demikian pula temuan Suprayitno (2011) bahwa semakin intens penyuluh menjalankan perannya, maka kemampuan petani semakin meningkat.

Materi yang diberikan oleh penyuluh kepada masyarakat telah disesuaikan dengan kebutuhan masyarakat dan disampaikan dengan metode-metode yang dianggap tepat dengan kondisi masyarakat. Kegiatan yang telah dilakukan oleh penyuluh sejalan dengan pendapat Sudjana (2000) bahwa pendekatan pembelajaran yang berpusatkan pada peserta didik menghasilkan keterlibatan peserta didik yang tinggi, umpan balik lebih akurat, dan proses belajar dapat dilakukan lebih optimal dibandingkan dengan menggunakan pende-katan pembelajaran yang berpusatkan pada pendidik atau fasilitator. Implikasi dari kesesuaian dan ketepatan metode penyuluhan adalah terjadinya peningkatan perilaku masyarakat ke arah yang lebih baik dalam melestarikan hutan mangrove. Hal ini juga didukung pula oleh frekuensi kunjungan penyuluh yang cukup intens.

Ketersediaan sarana yang memadai telah menunjang aktivitas masyarakat, diantaranya adalah 
ketersediaan lokasi pembibitan, tersedianya perahu kecil atau jolloro yang dapat digunakan sebagai alat transportasi guna memantau atau memonitor kondisi kawasan hutan mangrove. Dengan adanya sarana tersebut, masyarakat merasa cukup terbantu karena mampu mendukung kegiatan-kegiatan masyarakat. Dari hasil wawancara dengan masyarakat menyatakan bahwa sarana yang ada sudah cukup mampu membuat usaha masyarakat dalam kegiatan pengelolaan hutan mangrove. Antara masyarakat dengan pihak lain seperti penampung, rumah makan, dan pembeli lainnya telah terjalin kerjasama yang baik, sehingga dapat semakin mendorong peningkatan produktivitas usaha. Produk-tivitas usaha yang dilakukan oleh masyarakat adalah budidaya tambak ikan, udang dan penangkaran kepiting. Hal ini tidak terlepas dari keterlibatan para penyuluh lapang. Materi pembelajaran yang disampaikan penyuluh secara intens, membuat masyarakat dapat memecahkan masalah yang dihadapi dan mampu menjalin kemitraan dengan pihak lain demi kelancaran produksi.

Terdapat hubungan positif nyata antara indikator-indikator dukungan lingkungan dengan indikator-indikator perilaku masyarakat dalam upaya pelestarian hutan mangrove, (Tabel 3). Semakin tinggi dukungan lingkungan yang meliputi dukungan tokoh masyarakat, kelompok tani dan pemerintah maka semakin baik pula perilaku masyarakat dalam memanfaatkan dan mengelola hutan mangrove serta semakin meningkat kreativitas masyarakat dalam membangun kemitraan. Dengan kata lain, perilaku masyarakat sekitar hutan mangrove pada dasarnya bergantung pada pada situasi dan kondisi lingkungan dan berbagai peristiwa yang terjadi. Artinya bahwa lingkungan sosial, budaya dan alam memiliki hubungan positif terhadap perilaku masyarakat, sebagaimana pendapat Rakhmat (2002) dan Sarwono (2002) bahwa proses belajar melalui interaksi dan hubungan sosial dapat melahirkan motif sosiogenik pada diri individu yang berperan membentuk perilaku sosial. Motif sosiogenik adalah dorongan dari dalam diri untuk bertindak sebagai akibat atau adanya pengaruh orang lain. Temuan ini sejalan dengan temuan Santosa (2004) bahwa lingkungan sosial memiliki pengaruh yang besar terhadap perilaku adaptif petani tepian hutan. Begitu pula temuan Utama (2010) bahwa dukungan lingkungan merupakan kekuatan dan kualitas dari luar diri petani hutan yang secara langsung mempengaruhi tingkat keberdayaan petani sekitar hutan dalam mengelola hutan, cukup mampu memberikan dukungan bagi masyarakat dalam pelestarian hutan mangrove.

Tokoh masyarakat yang meliputi lurah, ketua RT atau ketua kelompok tani merupakan elemen penting dalam mendukung tumbuhnya perilaku positif masyarakat dalam upaya melestarikan hutan mangrove. Mereka dianggap oleh masyarakat memiliki pengaruh, status sosial, kewibawaan serta pola pikir dan wawasan yang lebih luas dalam memandang kehidupan. Peran tokoh masyarakat di lokasi penelitian sangat dirasakan manfaatnya oleh masyarakat. Tokoh masyarakat setempat sering membantu para petani memecahkan persoalan yang mereka hadapi baik yang terkait dengan pengelolaan hutan mangrove maupun berkaitan dengan usahausaha lain. Dalam pemanfaatan dan pengelolaan hutan mangrove, tokoh masyarakat seringkali memberikan saran dan arahan yang bermanfaat bagi mereka. Tokoh masyarakat juga biasanya aktif mencari informasi dari luar atau mencarikan rekan kerja sama bagi masyarakat, sehingga dapat menunjang produktivitas usaha mereka.

Hasil penelitian menunjukkan bahwa terdapat hubungan positif dukungan kelompok tani dengan perilaku masyarakat dalam melestarikan hutan mangrove. Semakin tinggi dukungan dari kelompok tani, maka semakin tinggi pula perilaku masyarakat dalam mengelola hutan mangrove. Keberadaan kelompok tani di lokasi penelitian dirasakan telah mendukung terciptanya perilaku positif masyarakat dalam memanfaatkan dan juga memelihara hutan mangrove. Dari hasil wawancara, masyarakat merasakan bahwa keberadaan kelompok tani sampai dengan saat ini mampu mendukung usaha-usaha ekonomi masyarakat, baik usaha untuk melestarikan hutan mangrove maupun usaha lainnya. Dukungan kelompok tani dalam pemanfaatan dan pengelolaan hutan adalah dengan terbentuknya aturan-aturan, nilai, kesepakatan dalam masyarakat yang berkaitan dengan pengelolaan hutan mangrove. Aturanaturan tersebut merupakan hasil kesepakatan anggota kelompok, yang telah dijalankan sejak awal pengelolaan kawasan hutan mangrove, misalnya aturan dilarang menebang pohon mangrove untuk perluasan tambak dan atau pembukaan lahan baru menjadi tambak di bagian wilayah pesisir dan laut yang ditetapkan berdasarkan karateristik 
fisik, biologi, sosial, dan ekonomi untuk tetap dipertahankan keberadaannya.

Kreativitas membangun kemitraan semakin tinggi dengan adanya dukungan kelompok tani. Kerjasama antara masyarakat dengan pihak luar dibangun dalam wadah kelompok. Kelompok tani ini menjadi mitra kerja dengan pihak luar. Keberadaan kelompok tani telah menumbuhkan rasa percaya diri petani untuk tetap berkembang. Tumbuhnya rasa kebersamaan dalam kelompok, berdampak pada kemampuan masyarakat dalam mengelola hutan mangrove menjadi lebih baik. Hubungan kemitraan di Kelurahan Tekolabbua termanifestasi dalam bentuk hubungan dagang, antara lain transaksi penjualan bibit tanaman mangrove.

Dukungan pemerintah merupakan hal yang sangat penting pada perubahan perilaku masyarakat dalam mengelola hutan mangrove. Keputusan dan kebijakan yang dibuat oleh pemerintah sangat menentukan besarnya persepsi masyarakat terhadap kesempatan untuk mengelola kawasan hutan mangrove. Pemberian kesempatan atau peluang kepada masyarakat untuk mengelola hutan mangrove sesuai dengan kebutuhan, tanpa mengabaikan aspek kelestariannya, akan mendorong masyarakat untuk berpartisipasi dalam pengelolaan hutan mangrove. Slamet (2003) mengemukakan bahwa kesempatan atau peluang untuk berpartisipasi harus tersedia agar masyarakat terdorong untuk membangun dan merubah kualitas hidupnya. Apabila kesempatan yang ada kecil maka sulit bagi seseorang untuk terdorong mengembangkan dirinya. Oleh karena itu pemerintah sebagai pembuat berbagai aturan, kebijakan atau regulasi terkait dengan pihak-pihak yang terlibat dalam pengelolaan hutan khususnya hutan mangrove, sebaiknya tidak membatasi akses dan keterlibatan masyarakat dalam mengelola hutan. Kebijakan pengelolaan hutan yang berpihak pada kebutuhan dan kepentingan masyarakat sekitar hutan mangrove, atau lebih mendukung masyarakat untuk mengakses dan terlibat dalam pengelolaan wilayah hutan dengan pertimbangan bahwa masyarakat sekitar hutan memahami dan telah memiliki kearifan untuk mengelola hutan mangrove secara lestari akan melahirkan sikap yang positif masyarakat terhadap pemerintah dan juga terhadap eksistensi hutan itu sendiri. Rasa tanggung jawab dan rasa memiliki terhadap kelestarian hutan akan muncul, karena hutan merupakan sumber pendapatan bagi mereka dalam memenuhi kebutuhan hidupnya.

\section{Kesimpulan}

Perilaku masyarakat dalam upaya pelestarian hutan mangrove di Kabupaten Pangkep termasuk kategori sedang, Masyarakat telah memanfaatkan hutan mangrove sesuai dengan kebutuhan dan pengelolaan yang dilakukan sudah berjalan baik dengan mengedepankan aspek kelestarian. Disamping itu masyarakat telah memiliki kreativitas dalam membangun kemitraan dengan pihak lain terkait dengan pengelolaan dan pelestarian hutan mangrove.

Faktor-faktor yang berhubungan dengan perilaku masyarakat dalam pelestarian hutan mangrove adalah intensitas penyuluhan yang meliputi frekuensi kunjungan penyuluh, kesesuaian materi, ketepatan metode dan juga ketersediaan sarana, serta adanya dukungan lingkungan yang meliputi dukungan tokoh masyarakat, dukungan kelompok tani dan dukungan pemerintah.

\section{Daftar Pustaka}

Chadwick AB, Bahr MH, Albrecht LS. 1991. Metode Penelitian 1lmu Pengetahuan Sosial. Sulistia ML, Mujianto Y, Sofwan A, Suharjito, penerjemah. Semarang (ID): IKIP.

Konsorsium Mitra Bahari Sulawesi Selatan. 2010. Focos on mangrove [Internet]. [dapat diunduh dari: http://www.kmb-suwww.kmbsulsel.net].

Mayudin A. 2012. Kondisi Ekonomi Pasca Konversi Hutan Mangrove Menjadi Lahan Tambak Di Kabupaten Pangkajene Kepulauan Provinsi Sulawesi Selatan. Jurnal EKSOS 8(2): 90-104. ISSN. 1693 - 9093.

Nurfiarini A. 2003. Kajian Pengembangan Budidaya Perikanan Pesisir Dan Pengaruhnya Terhadap Kondisi Sosial Ekonomi Masyarakat di Teluk Saleh Kabupaten Dompu [tesis]. Bogor (ID): Institut Pertanian Bogor.

Rakhmat J. 2002. Psikologi Komunikasi. Bandung (ID): Remaja Rosdakarya.

Raymond Graziano P, Harahap N, Soemarno. 2010. Pengelolaan Hutan Mangrove Berbasis Masyarakat di

Kecamatan Gending. Jurnal Agritek 18(2): 184-200. ISSN. 0852-5426. 
Santosa I. 2004. Pemberdayaan Petani Tepian Hutan Melalui Pembaharuan Perilaku Adaptif [disertasi]. Bogor (ID): Institut Pertanian Bogor. Sarwono SW. 2002. Psikologi Sosial, Individu dan Teori-Teori Psikologi Sosial. Jakarta (ID): Balai Pustaka.

Sevilla CG, Ochave JA, Punsalan TG, Regala BP, Uriarte GG. 1993. Pengantar Metode Penelitian. Tuwu A, penerjemah. Jakarta (ID): U1 Pr.

Slamet M. 2003. Membentuk Pola Perilaku Manusia Pembangunan. Bogor (ID): IPB Press.

Sudjana D. 2000. Strategi Pembelajaran. Bandung (ID): Falah Production.

Sujarwo. 2004. Pengetahuan, Sikap dan Tindakan Masyarakat dalam Pelestarian Hutan. [tesis].
Bogor (ID): Institut Pertanian Bogor.

Suprayitno AR. 2011. Model Peningkatan Partisipasi Petani Sekitar Hutan Dalam Mengelola Hutan Kemiri Rakyat. [disertasi]. Bogor (ID): Institut Pertanian Bogor.

Tantu AG. 2012. Evaluasi Kesesuaian Lahan Untuk Pemanfaatan Sumbardaya Alam Pesisir Berkelanjutan [disertasi]. Makassar (ID): Universitas Hasanuddin.

Tribun-Timur. 2011. 70 Persen Mangrove Sulsel Rusak [Internet]. [dapat diunduh dari: http:// makassar.tribunnews.com].

Utama S. 2010.Pemberdayaan Masyarakat Sekitar Hutan Melalui Pendekatan Kelompok. [disertasi]. Bogor (ID): Institut Pertanian Bogor. 